\title{
STRATEGI BAHASA PERSUASI DALAM MEMASARKAN KIMONO BOOKMARK SEBAGAI BENTUK PRAKTIK KEWIRAUSAHAAN
}

\author{
Fajar Kurniadi $^{1}$, Askardiya Mirza Gayatri ${ }^{2}$, Septiana Ika Ningtyas ${ }^{3}$ \\ ${ }^{123}$ Program Studi Pendidikan Ekonomi Universitas Indraprasta PGRI \\ Email: fajar.kurniadi@unindra.ac.id
}

\begin{abstract}
Entrepreneurship is a mental attitude that often echoed not only by government but also by the educator. The purpose of the act is to activate the role of community or educator in Indonesia economic domain. Several methods have been applied for smoothening the purpose, one of them is the utilization of waste and transform it into the worth of selling goods. The utilization of patchwork and transform it into kimono modeled bookmark become the solution to some of the problems, namely waste, creativity presence, and entrepreneurship. This activity is done in a few stage, which is sorting patchwork waste, the making of a bookmark, and sell it using various media. The most preferred media is social media with its various features. Starting with the feature that uniting pictures up till using language that persuades buyers at least to look at the products that was on sale feature. The scope of this activity is vocational high school students especially office administration major which familiar with recording and bookkeeping. The purpose of this activity is growing the interest in entrepreneurship, enhance creativity by making patterns and shape as well as rising the use of persuasive language in products marketing. The result of this activities is bookmark with several models and the sale of the bookmark in social media using some of persuasive language and style.
\end{abstract}

Keywords: Persuasive, Entrepreneurship, Waste

\begin{abstract}
Abstrak Kewirausaahaan merupakan sikap mental yang sedang banyak digaungkan pemerintah, termasuk pendidik. Adapun kegunaannya adalah untuk mengaktifkan peran masyarakat atau pendidik dalam kancah perekonomian Indonesia. Beberapa praktik diterapkan untuk memuluskan tujuan tersebut, salah satunya adalah pemanfaatan limbah menjadi barang layak jual. Pemanfaatan kain perca menjadi pembatas buku dengan model kimono menjadi jalan keluar dari beberapa masalah yakni limbah, pemunculan kreativitas, dan berwirausaha. Kegiatan ini dilakukan dengan beberapa tahap, yakni tahap pemilahan limbah perca, pembuatan pembatas buku, dan menjualnya dengan berbagai media. Media paling digemari adalah media sosial dengan berbagai fiturnya. Mulai dari fitur menyatukan gambar hingga penggunaan bahasa yang mengajak pembeli setidaknya melihat produk yang dijual. Lingkup kegiatan ini adalah siswa SMK khususnya jurusan Administrasi Perkantoran yang sudah akrab dengan pencatatan dan pembukuan. Tujuan kegiatan ini adalah menumbuhkan minat kewirausahaan, meningkatkan kreativitas dengan membuat pola dan bentuk serta menumbuhkan semangat penggunaan bahasa persuasi dalam memasarkan produknya. Hasil yang diperoleh dari kegiatan ini adalah pembatas buku dengan beberapa model dan penjualannya di media sosial dengan menggunakan beberapa gaya dan bahasa persuasi.
\end{abstract}

Kata Kunci: Persuasi, Kewirausahaan, Limbah

\section{PENDAHULUAN}

Penandatangan nota kesepahaman mengenai Masyarakat Ekonomi ASEAN di akhir tahun 2015 merupakan momentum nyata dibukanya peluang dan tantangan bagi perekonomian para pelakunya, termasuk Indonesia. Indonesia menjadi salah satu anggota yang menyetujuinya dan bersiap menghadapi gencarnya produk dan jasa yang hadir dari mancanegara. Peluang terjadi jika para pelaku usaha Indonesia mengembangkan produknya untuk dikirim dan dipasarkan di negara tujuan MEA. Peluang memperluas daerah pemasaran merupakan satu dari beberapa keuntungan MEA ini. Daerah pemasaran yang luas akan membuat produk semakin banyak tersebar dan diminati oleh berbagai orang dari berbagai kalangan di negara-negara lain. Negara pun ikut merasakan berkah dari peristiwa ini dengan masuknya devisa dan bea masuk barang.

Ancaman terjadi jika produk yang dijual tidak sesuai dengan kualifikasi minimal negara tujuan atau kurang diminatinya produk. Ditambah lagi, dari dalam negeri, budaya konsumtif masyarakat Indonesia dapat membuat produk hasil negeri sendiri kalah bersaing dengan produk dari luar negeri. Kegemaran menggunakan produk bermerek dan luar negeri 
merupakan momok menakutkan bagi pelaku usaha domestik. Produk impor gencar dipromosikan di berbagai media dengan cara dan model yang menarik sehingga mudah masuk ke ingatan para konsumen. Ditambah, stigma barang impor adalah barang berkualitas sangat melekat dan sulit dihilangkan pun menjadi penunjang larisnya produk impor di pasar Indonesia. Tengok saja produk elektronik atau kendaraan, penguasa segmen ini adalah produk dari negara lain. Melihat kondisi ini, pemerintah mulai gencar mencanangkan program berwira usaha. Melalui semangat wira usaha, diharapkan dapat memotivasi pegiat wira usaha muda termasuk para konsumen untuk berpindah produk ke produk lokal dengan manfaat untuk negeri sendiri. Mengubah stigma di atas bukanlah hal mudah tetapi tidak ada yang tidak mungkin. Jika pasar dibanjiri produk lokal berkualitas, tentunya pola konsumen akan berubah ke produk lokal. Semangat cinta kebangsaan pun digelorakan untuk meningkatkan daya beli produk lokal. Hal ini nampaknya berdampak positif dengan banyaknya para wirausahawan muda berbakat dan tidak segan mempromosikan produknya di level internasional. Mereka membangun jaringan kuat antarnegara dengan memadukan kreativitas dan kemajuan teknologi. Tengok saja pemilik makanan khas Turki asal Indonesia yang sudah menjangkau 9 (sembilan) negara dengan lebih dari 1300 cabang di Indonesia (anonim, 2017).

Semangat membumikan kewirausaan sudah muncul di bangku sekolah dengan menerapkan mata pelajaran kewirausahaan. Perguruan tinggi pun mengambil peran dalam semangat ini dengan mengintegrasikan mata kuliah kewirausahaan pada semester 6 (enam) dan 8 (delapan). Di semester 6, mahasiswa dibekali dengan teori berwirausaha dan pembuatan proposal wira usaha. Di semester 8, mahasiswa diminta berperan aktif dalam kegiatan kewirausahaan dengan membuat produk hingga memasarkannya. Namun, penanaman minat kewirausahaan ternyata sudah digalakkan sejak anak usia dini. (Kurniadi, 2015) pernah meneliti mengenai hal ini dan menghasilkan "Pembangunan minat kewirausahaan sebaiknya dilakukan di lingkungan pendidikan dini sebagai peletakkan landasan ekonomi yang kuat"

$$
\text { Berdasarkan penelitian tersebut, }
$$
penanaman minat kewirausahaan harus dilakukan sejak dini guna melandasi pengetahuan ekonomi yang kuat. Semakin dini tentunya semakin baik tanpa mengabaikan batasan usia dan ketentuan lingkungan. Penanaman harus dilakukan dengan memerhatikan usia, tidak perlu dilakukan dengan tergesa-gesa dan terlalu memikirkan target. Sikap yang didahulukan adalah bermain sambil belajar. Menanamkan sebuah pelajaran dengan cara yang menyenangkan dan bermanfaat. Peneliti membungkusnya dengan berbagai bahasa yang menarik perhatian anak PAUD sehingga mereka mau mengikuti arahan tanpa merasa dipaksa.

Tidak hanya di lingkungan pendidikan, pemerintah pun giat membumikan kewirausahaan di kalangan masyarakat dengan membuat kementerian Koperasi dan Usaha Kecil dan Menengah untuk menggiatkan kembali sektor ekonomi dimulai dari sendi terkecil. Salah satu yang digagas oleh Kementerian (Koperasi, 2015) ini adalah dengan mengeluarkan peraturan yang menyediakan fasilitas kemudahan impor bagi koperasi dan usaha mikro kecil dan menengah untuk mengembangkan produk-produk tujuan ekspor. Melalui aturan ini, diharapkan koperasi dan UMKM mampu berkembang luas di semua daerah untuk memproduksi barang kebutuhan masyarakat dan ekspor termasuk produk-produk ekonomi kreatif yang menjadi karakter produk hasil usaha serta mampu bersaing dengan produk impor yang merambah pasar ASEAN. Selain mengatur regulasi dan manajemen pemasarannya, pemerintah pun rutin mengadakan bazar atau penjualan barang hasil wirausahawan muda. Hal ini diharapkan dapat membuat geliat wirausaha menjadi semakin banyak dan variatif, termasuk geliat di media sosial.

Media sosial sudah bukan barang baru untuk kehidupan manusia di era mileneal ini. Pengguna internet di Indonesia yang mencapai 123.000 pengguna (Hidayat, 2014) merupakan angka yang fantastis dan menduduki posisi ke-6 dunia. Jumlah pengguna yang luar biasa merupakan sebuah peluang bagi para 
wirausahawan untuk mengembangkan pasar penjualan produknya melewati batas ruang dan waktu. Melalui fasilitas media sosial, hambatan ruang dan waktu, persaingan tempat dan harga dapat diminimalisasi. Pemasaran tidak perlu dilakukan di pasar, bahkan di dalam kamar pun dapat membuka toko digital dengan memajang foto barang dan dapat dilihat oleh semua pengakses internet. Kemudahan ini membuat geliat pasar digital semakin pesat dan tidak terbendung. Permasalahannya adalah ketika banyak barang yang diperjualbelikan dengan berbagai kemiripan membuat para pembeli bingung menentukan pilihan. Oleh karena itu, penjualan di toko digital pun harus menggunakan trik penarik konsumen dengan bahasa yang persuasif.

Persuasi merupakan tulisan yang digunakan untuk menuangkan ide dan gagasan dengan mengajak lawan tutur atau pembaca dan pada akhirnya adalah meyakinkan orang lain. Bentuk persuasif tidak hanya dalam media tulis melainkan media komunikasi lainnya. Komunikasi persuasif merupakan komunikasi yang mempunyai tujuan khusus dan terarah untuk mengubah perilaku sebagai sasaran komunikasi.

Jika dikaitkan dengan paragraf, persuasi merupakan paragraf dengan tujuan mengajak, membujuk, atau merayu dengan tujuan akhir mempenagaruhi hingga mengajak pembaca atau penyimak melakukan apa yang diinginkan penulis atau pembicara. Ada pun ciri dari paragraf ini adalah menyajikan fakta, pemberian alasan, dan membujuk. Biasanya menggunakan partikel bahasa -lah atau dengan slogan atau jargon tertentu yang menjadi ciri khas sebuah tempat atau produk.

Kaitannya dengan pemasaran produk, gaya atau bahasa mengandung unsur persuasif dibutuhkan untuk menarik perhatian calon pelanggan. Bahasa persuasif pun bukan sekadar tuturan atau tulisan yang mengajak, tetapi pemuatan gambar atau gerak tubuh pun masuk kategori penggunaan persuasif. Tengok saja sebuah pusat perbelanjaan yang membuat jargonnya dengan memanggil semua calon konsumennya dengan sapaan "Kakak!" untuk membuat calon konsumennya nyaman dan akrab. Kenyamanan dan keakaraban yang dijalin penjual kepada pembeli akan membuat proses memasarkan dan bertransaksi menjadi lebih mudah dan menyenangkan. Selain penggunaan bahasa persuasif, peranan negosiasi pun sangat penting dalam proses transaksi.

\section{METODE PELAKSANAAN}

Pelaksanaan pengabdian ini dilakukan dengan melakukan penyuluhan. Penyuluhan yang dilakukan dengan membangkitkan semangat peserta didik untuk dapat memaksimalkan potensi dan kreativitas dengan membuat barang layak pakai dengan bahan sisa produksi. Penyuluhan pun dilakukan untuk memberikan gambaran keseruan berwirausaha dengan berbagai kemudahan dan keuntungan jika dikolaborasikan dengan media sosial.

Setelah penyuluhan dilakukan, praktik langsung ke objek abdian yakni para siswa. Sebelum melakukan penyuluhan, para siswa diajak untuk memilih dan memilah bahan baku yang akan dibuat kerajinan tangan yakni kain perca dan kertas berwarna. Melalui kegiatan ini, siswa dapat mengetahui model dan corak warna dari luarannya nanti. Setelah melakukan pemilihan, para siswa diajak untuk membuat pola hingga pada akhirnya mengikuti dan menyelesaikan karyanya. Setelah selesai, hasilnya langsung dipromosikan dengan berbagai media sosial mereka.

Kegiatan pengabdian kepada masyarakat ini dilakukan di SMK Waskito yang beralamat di Jalan Raya Pamulang 2, Serua, Ciputat, Tangerang Selatan, Provinsi Banten Jawa Barat Indonesia.

\section{HASIL DAN PEMBAHASAN}

Hasil yang didapatkan dari kegiatan pengabdian kepada masyarakat ini adalah produk pembatas buku dengan berbagai model dan warna. Sebelum menghasilkan produk tersebut, dilakukan beberapa proses lain yakni melakukan penyuluhan. 


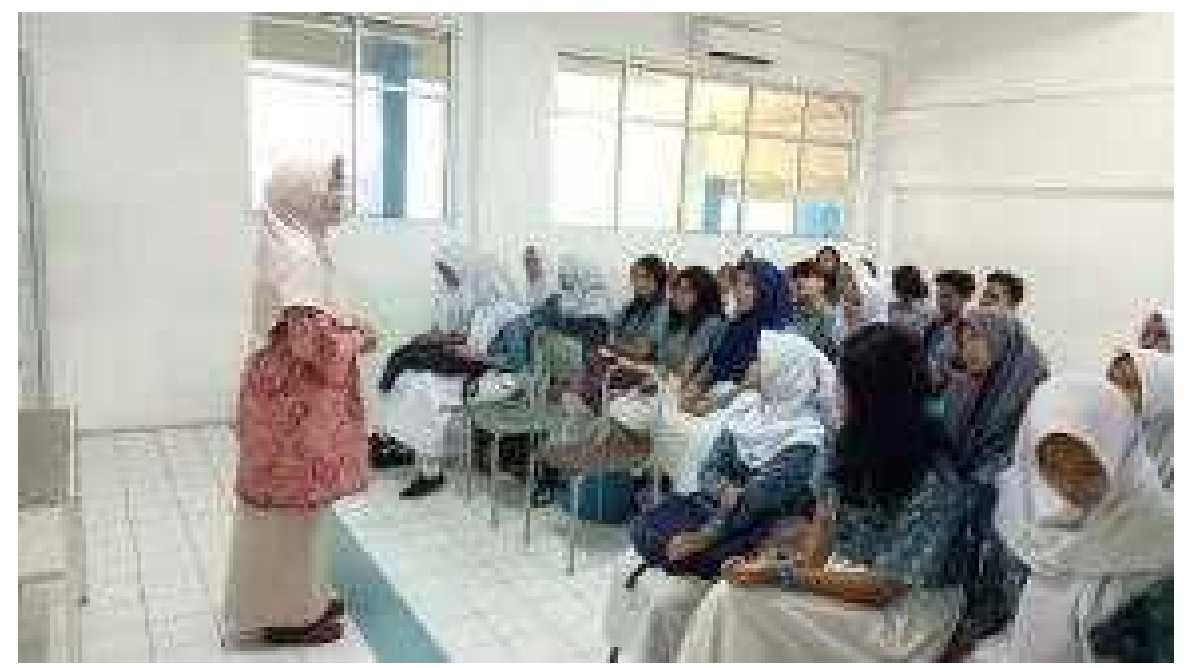

Gambar 1; Proses Penyuluhan Pentingnya Berwirausaha

Pada kegiatan penyuluhan, tim melakukan pencerahan dan penegasan bahwa berwirausaha adalah sebuah peluang di era milenia ini. beberapa contoh sukses para wirausahawan muda pun diberikan sebagai motivasi dan pendorong. Antusiasme para peserta didik pun semakin tinggi saat kami memberikan contoh produk layak jual yang ternyata dibuat dari barang yang sudah tidak digunakan.

Setelah proses penyuluhan dan memotivasi peserta didik, tindakan selanjutnya adalah membiarkan mereka berkreasi dengan imajinasi dan kreativitasnya. Mereka diizinkan melihat-lihat luaran produk dan bahan baku yang akan digunakan untuk membuat kerajinan. Proses memadupadankan bahan baku dengan imajinasi mereka merupakan langkah memotivasi dan membuat kreativitas mereka semakin berkembang. Setelah motivasi terbentuk, akan sangat mudah menggiatkan kegiatan baru. Proses selanjutnya adalah dengan melakukan pendampingan dalam pembuatan produk. Setiap tahap yang dilakukan, diperhatikan dengan saksama dan dibimbing dengan telaten dan penuh kesabaran. Kegiatan pendampingan ini melibatkan seluruh siswa, termasuk guru. Beberapa guru mulai dapat mengikuti setiap tahapan yang dilakukan dan kembali mengajarkan kepada peserta didiknya 


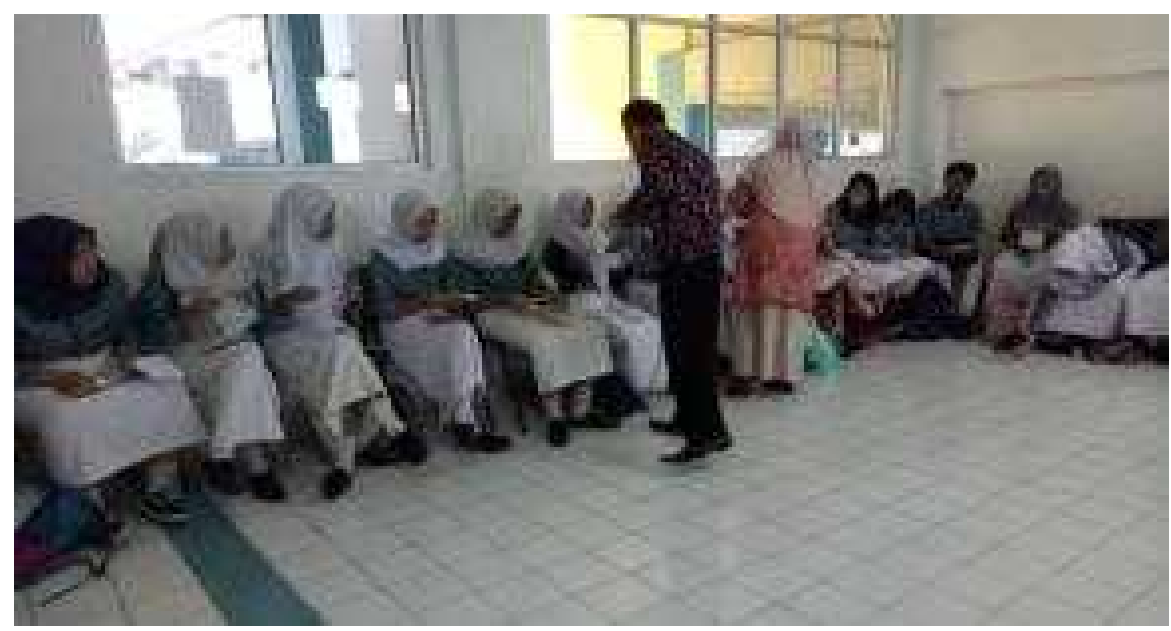

Gambar 2. Proses Pendampingan Pembuatan Kimono Bookmark

Alat dan bahan yang digunakan dalam kegiatan ini adalah kain perca, lem kertas, potongan kertas warna, pita warna, kertas karton yang telah dipotong sedemikian rupa. Adapun perlakuan yang diberikan kepada bahan ini adalah sebagai berikut: a. Melipat kertas bercorak dengan lipatan kecil di bagian atas ukuran 1-2 milimeter lalu direkatkan dengan lem, sisihkan; b. Ambil kertas karton berwarna yang digunakan sebagai alas atau badan pembatas buku, lalu rekatkan dengan bagian pertama tadi. Jika sudah direkatkan, lipat kertas berwarna secara menyilang ke bagian depan; c. Setelah itu, kita akan membuat bagian kepala dengan menyusun atau menempelkan bagian kecil yang telah dibuat dengan menggunting karton dalam bentuk lingkaran kecil. Besar lingkaran itu harus disesuaikan dengan badan atau tubuh pembatas buku. Setelah dibuat, bagian ini disatukan dengan merekatkannya; d. Setelah direkatkan, tinggal membuat model untuk bagian kepala.

Untuk membuat model ini, siswa diberikan kebebasan untuk mengkreasikannya. Bahan yang dijadikan rambut ini diambil dari beberapa helai kertas warna atau pita atau jalinan benang wol beraneka warna; e. Setelah semuanya tergabung, proses selanjutnya adalah mengemasnya dengan plastik dan pita beraneka warna agar terlihat elegan dan layak jual. Proses pembuatan telah selesai dilakukan, selanjutnya adalah proses pemasaran dan penjualan. Beberapa trik dilakukan agar produk yang telah dihasilkan mampu menarik perhatian calon pembeli, salah satunya adalah pemanfaatan media sosial dan menggunakan bahasa komunikasi persuasif.

Kebanyakan siswa telah memiliki media sosial dengan banyak pengikut di antaranya adalah rekan siswa di berbagai sekolah. Hal ini merupakan sebuah peluang yang harus dimanfaatkan dengan baik. Berbekal produk yang sudah dibuat dengan cantik dan layak jual, mereka pun tidak ragu memasarkannya di media sosial. Gaya persuasif yang diperlihatkan para siswa adalah dengan menyusun produk luaran dengan sedemikian rupa dengan menggunakan kreasi yang menarik. Beberapa membuat vidio singkat dan diunggah ke media sosialnya. "Yuk baca buku, jangan lupa percantik bukumu dengan Kimono Bookmark! Mumpung masa promosi, beli 2 gratis 1!" merupakan salah satu bentuk tulisan yang diunggah siswa di media sosialnya dengan mencantumkan beberapa gambar contoh produk.

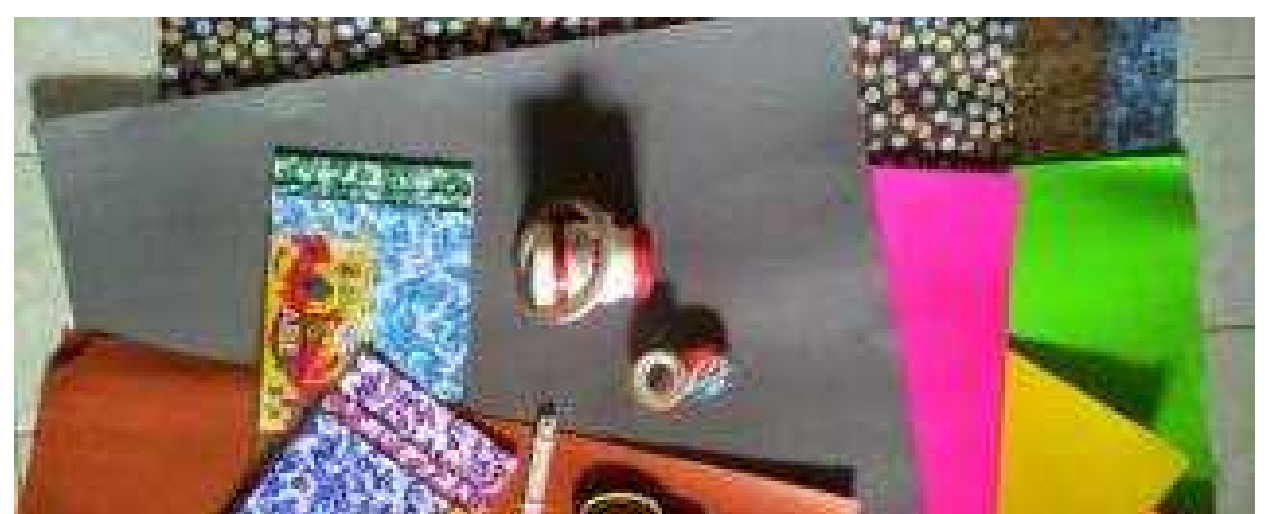




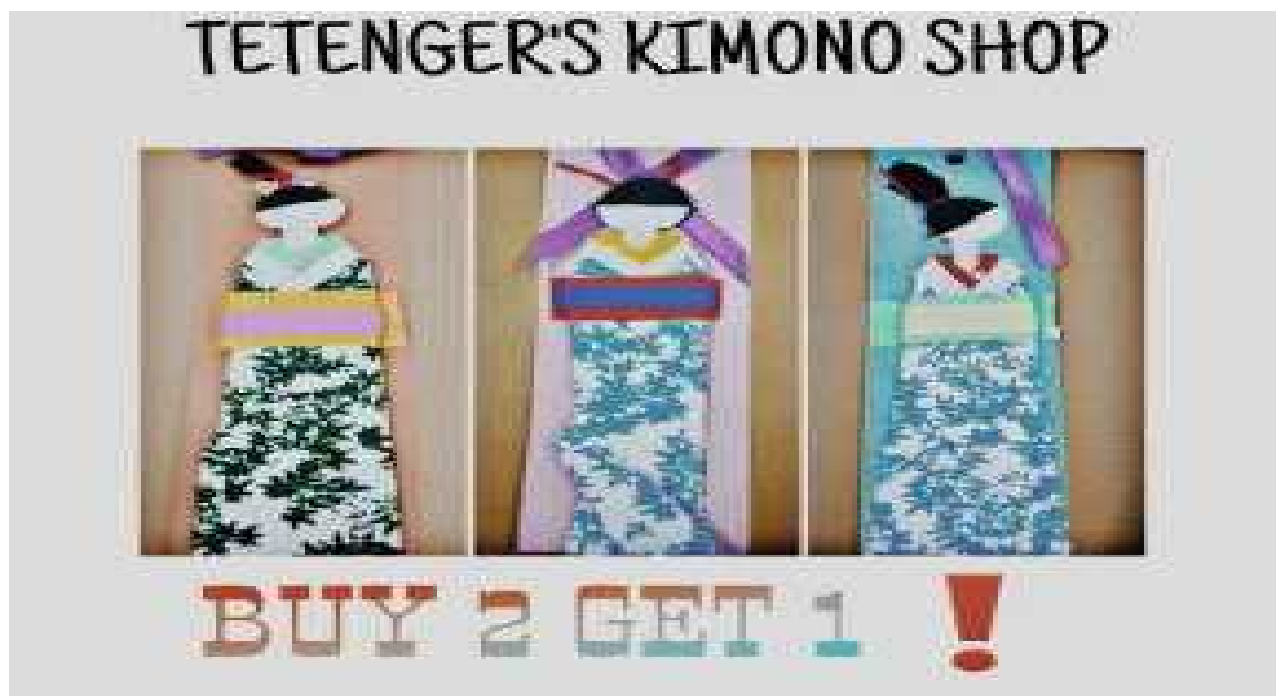

\section{Gambar 4; Salah Satu Proses Pemasaran lewat Media Sosial}

Bahasa persuasi yang digunakan pada iklan pemasaran ini adalah dengan menunjukkan masa promosi. Calon konsumen akan tertarik jika mendengar atau melihat kata "Potongan Harga", "Gratis", "Beli X dapat Y dan Z", atau dengan stimulasi bahasa "Promo hanya hari ini" dengan tampilan yang menarik dan warna yang mencolok. Pemajangan barang atau produk di tempat yang mudah dilihat pun merupakan bahasa persuasif yang sangat efektif. Termasuk memperluas daya sebar promosi dengan berbagai cara, diantaranya menyebarkan pamflet dan leaflet, membuat spanduk besar, pemasangan iklan di media televisi atau media sosial.

Melalui pemasaran di media sosial, eksistensi mereka sebagai wirausahawan muda terbangun dan membuat mereka bersemangat untuk menciptakan produk-produk sejenis. Ditambah lagi dengan menggunakan bahasa persuasif yang kuat dapat membuat produk mereka terjual laris di pasaran sesama siswa.

Bahasa persuasif yang ditampilkan bukan hanya berbentuk bahasa, pengaplikasian produk pada beberapa media yang sering digunakan siswa pun dapat menjadikan proses pemasaran menjadi mudah. Contohnya adalah dengan
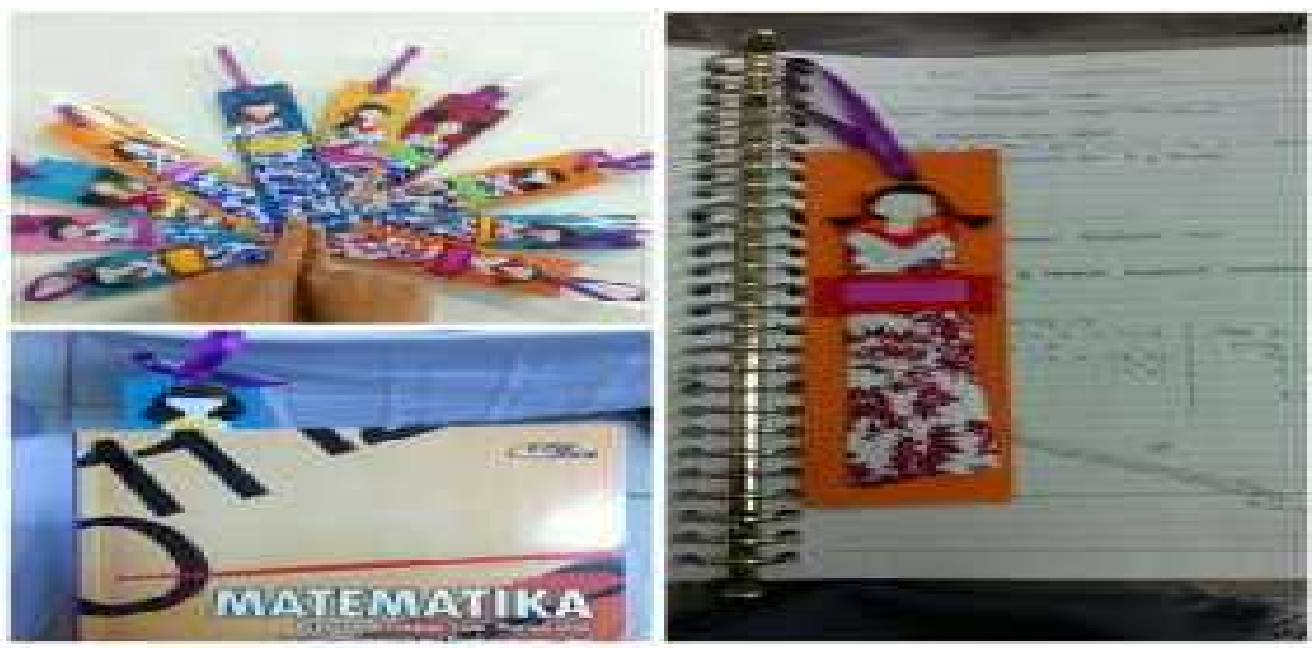
menggunakan Kimono Bookmark ini sebagai

kekinian.

pembatas buku pelajaran dengan gaya yang

Gambar 5. Salah Satu bentuk bahasa Persuasif dalam pemasaran Komono Bookmark

Bahasa persuasif yang diterapkan pada gambar pemasaran di atas adalah dengan menunjukkan pola penggunaan produk luaran sehingga konsumen dapat merasakan sensasi yang diberikan oleh produk. Lewat cara ini, diharapkan produk dapat menarik para calon konsumen dan dibeli karena beraneka ragam dari segi warna, bentuk, dan aksesorisnya. Bahasa persuasif yang dibungkus dengan tingkat kekinian para siswa membuat produk mudah tersebar.

\section{SIMPULAN DAN SARAN}

Berdasarkan kegiatan yang telah dilakukan, dapat disimpulkan beberapa pernyataan sebagai berikut:

a. Berwirausaha merupakan kegiatan menciptakan, mengolah, hingga memasarkan produk baru dan bernilai jual kepada khalayak. Berwirausaha merupakan tantangan manusia di era milenial jika tidak mau hanya menjadi makhluk penganut konsumerisme. Selain membuka peluang, berwirausaha pun dinilai ramah lingkungan dan ekonomi. Jika dapat membuat, untuk apa membeli!

b. Berwirausaha pun harus dilakukan mengikuti kemajuan teknologi dengan memanfaatkan berbagai fitur dan kelancaran jaringan komunikasi. Berbagai aplikasi media sosial dengan berbagai fitur menarik dan memanjakan para wirausahawan muda teleh menanti untuk dimanfaatkan. Pemanfaatan media sosial dapat sangat efektif karena tidak membutuhkan banyak tenaga, uang, dan usaha. Para pengguna media sosial tidak perlu menyewa toko, membayar karyawan, retribusi, area parkir, bayar iuran listrik, dan pajak (belum diatur). Peluang inilah yang menjadi modal yang sangat berharga bagi para wirausahawan muda di era milenial. Selain dukungan media, manusia era milenial dinilai sangat kreatif dan mempunyai mobilisasi yang tinggi. Berbagai konten digital dan penjualan digital hampir menguasai perekonomian saat ini.

Berdasarkan simpulan yang telah diraih, ami memberikan rekomendasi atau saran sebagai berikut:

a. Melihat pada banyaknya potensi yang ada pada siswa dan media sosial, perlu diadakan kegiatan serupa dengan cakupan lebih luas dan tim yang lebih banyak. Pembinaan kewirausahaan di sekolah pun harus lebih diarahkan pada praktik dibandingkan teori.

b. Minat yang sudah tumbuh, harus difasilitasi oleh pihak berwenang. Dalam hal ini, pihak sekolah diharapkan memberikan ruang bagi wirausahawan muda di sekolah dengan mengadakan semacam bazar rutin bulanan atau semesteran. Perhelatan ini pun dinilai untuk menimbulkan gairah berwirausaha siswa.

\section{UCAPAN TERIMA KASIH}

Alhamdulillah, puji serta syukur kami haturkan kepada Allah SWT yang telah memberikan semua nikmat-Nya sehingga kami masih mampu menjalani hidup dengan penuh keberkahan. Aamiin

Ucapan terima kasih kami berikan kepada semua pihak yang telah membantu dalam kegiatan ini, mulai dari perencanaan hingga evaluasi. Utamanya adalah mitra kami yakni SMK Waskito Ciputat yang telah bersedia menerima kami untuk dapat menerapkan ilmu kami di sana.

Terima kasih pula untuk seluruh rekan dosen di Universitas Indraprasta PGRI yang telah menciptakan iklim kerja yang sangat kompetitif sehingga menimbulkan semangat kreativitas yang luar biasa. Semua itu tidak akan tercipta tanpa pemimpin yang bijaksana. Terima kasih yang tidak terhingga kepada Bapak H. Akhmad Sefudin S.E., M.M. yang telah sangat bijaksana membimbing rekan dosen sehingga mampu mengembangkan karier dengan baik. 
DAFTAR PUSTAKA

anonim. (2017, 12 19). Kebab Turki Baba Rafi. Retrieved 12 20, 2017, from Babarafi: www.babarafi.com/?lang=en

Hidayat, W. (2014, 11 24). Pengguna Internet Indonesia Nomor Enam Dunia. Retrieved $12 \quad 10, \quad 2017$, from Menengah. Retrieved 12 10, 2017, from Kementerian Koperasi dan Usaha Kecil dan Menengah Republik Indonesia: http://www.depkop.go.id/content/read/pe mberdayaan-koperasi-dan-usaha-kecildan-menengah/
Kementerian Komunikasi dan Informatika Republik Indonesia: https://kominfo.go.id/content/detail/4286 /pengguna-internet-indonesia-nomorenam-dunia/0/sorotan_media

Koperasi, S. (2015, 9 15). Pemberdayaan Koperasi dan Usaha Kecil dan Kurniadi, F. (2015). Peranan Pembangunan Minat Kewirausahaan pada Siswa PAUD dalam Menyambut MEA dengan Model Menjual Karya Sendiri. Research and Development Journal of Education, 3-11 